UDC $\quad 669.14 .018 .29: 621.9 .016 .3$

\title{
低合金鋼の冷間鐉造性
}

渡辺輝 夫*

\section{Cold Forging Workability of Low Alloy Steel}

\section{Teruo Watanabe}

\section{Synopsis}

Investigating the cold forging characteristics of low alloy steels with low $P, S i$ and $S$ contents, the authors found that these steels have excellent cold forgeability.

\section{1. 緒}

\section{言}

冷鉔用鋼に要求される諸特性の5ち, 主要なるのは 变形抵抗が小さいことと変形能が大きいことに集約さ れる。これらの対策としては，Cを含めて合金成分を 低下すればよいわけであるが，これらの成分は，鋼の 最終の使用特性から決定されたものが大部分であり， 中間工程である冷間鍛造のために制御できる範囲はき わめて少ない。このため鍮の最終使用特性への影響が 小さく，かつ、冷䤨特性を著しく向上するための冶金 的な方策か種々検討されてきている。

変形抵抗を小さくするために, マトリックスへの固 溶強化か著しく大きく，かつ燒入性への影響が比較的 小さいものとしてPおよびSiが注目されている。

$\mathrm{P}$ 扰よび Si の固溶強化については, Bain ${ }^{11} か ゙$ エライトへのがさに著しく影響することを示したの

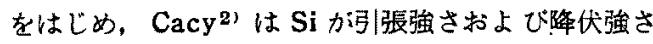
を著しく大きくすることをみたしており，炭素銅扰よ び合金鋼についてもSi が変形抵抗を著しく大きくす ることがわかっているる゙は5。

つきに変形能であるか，これにはは応力集中によるク ラックあるいはボイドの発生源およびクラックの伝播
経路となる非金属介在物が，あらゆる銅璉にとって影 響か大さい。特に細辰く伸ぴた状態で存在することの 多い硫化物については，変形能への影響力大きく，低 合金銅についてこれの増量によって絞りの低下のある いはフッブセット試験における限界ひずみの低下゙が みられることが唯認されている。

以上の上5に，これらの成分扰よび不純物か，基嘛 特性すなわち压縮試験值打よび引張試験值におよ洔す 影響を検討した報告はすでになされているが，冷錪の 広範囲な実用特性にまで結びつけたるのは少ない上5 である。このため中炭素銅と $\mathrm{Cr}-\mathrm{Mo}$ 鈴について， $\mathrm{P}, \mathrm{S}$ 打よび $\mathrm{Si}$ 含有量の低下か，冷䤵の㬰用特性に およぼす影響を明らかとすることをもくろみた。

\section{2. 供試材および实眙方法}

\section{1 供試材}

供試材はベースとして S45C およびS CM 3 を用 い。これらは実驗目的により真空溶解 (V)，誘導炉 溶解（I）およびフーク炉溶解（A）により溶製し， かつすべて球状化㜔䤞を施した。その詳細は各実験項 目に記する。 


\section{2 实酫方法}

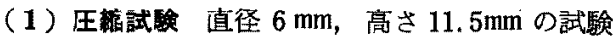
片をアムスラー試験機により，速度 $10 \mathrm{~mm} / \mathrm{min}$ で死 縮した。端面はモリループによりくり返し潤滑した。

（2）引張試直径 $10 \mathrm{~mm}$, 僄点距離 $50 \mathrm{~mm}$ の引 張試験片によった。

(3) 押出し加工 直徍 25 および $50 \mathrm{~mm}$ のブラン クを $600 t$, 40c.p.m.のマイプレス(ナックル・ジ ョイントプレス）により前方，前後方扰よび後方押出 しを行ない，加圧力，割れ発生および押出し品の品質 を測定した。加圧力はテンションロッドにはりつけた ワイヤーストレンゲージにより，ストロークは差動卜 フンスにて湘定した。ブランクの前処理はボンデライ ト 421 とボンダリューベ235の被膜と，さらに端面の みモリルーブを鍌布した。使用した工具形状を Fig* 1に示す。
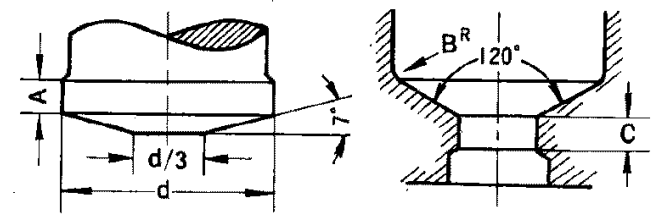

\begin{tabular}{|c|c|}
\hline Blank & A \\
\hline $25 \phi$ & 5 \\
\hline $50 \phi$ & 10 \\
\hline
\end{tabular}

Punch for backward and combined extrusion

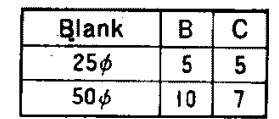

Die for forward
Fig. 1. Punch and die.

（4）バックリング性 直径 $6 \mathrm{~mm}$ の線材を両端拘 束で圧縮し，バックリンダせずに圧縮できる最大据込 及比を測定した。試験は $200 t$ 油圧プレスを用い，匤 縮速度は $38 \mathrm{~mm} / \mathrm{min}$ である。

（5）盛上り性 直径 $25 \mathrm{~mm}$ ，高さ $22 \mathrm{~mm}$ のブラン

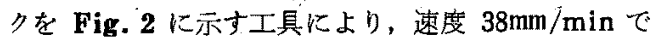
圧縮し，中心孔への盛上りの高さを測定した。

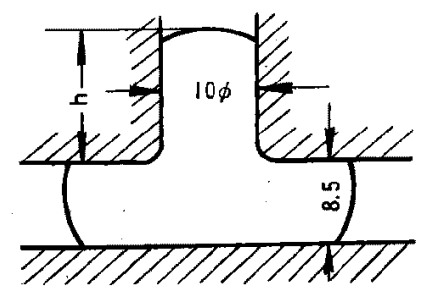

Fig. 2. Open-die extrusion.

（6）トリミンダ性 直径 $6 \mathrm{~mm}$, 高さ $11.5 \mathrm{~mm} の$ 試験片を $87 \%$ 据込んで厚さ $2 \mathrm{~mm} に し た$ 後, 穴径 8.4 $\mathrm{mm}$ ，前傾斜角 $3^{\circ}$ のトリミングダイスにより，クリフ ランス $0.2 \mathrm{~mm}$ でトリミングし，せん断力および製品 のかえり高さを測定した。

（7）フランクのせん断性 直径 $25 \mathrm{~mm}$ の棒材を， 半径 $12.5 \mathrm{~mm}$, 前傾斜解 $1^{\circ}$ の半円形カッターにより, クリアランス $0.15 \mathrm{~mm}$ で世ん断し，世ん断力扰よび切 口形状を測定した。せん断速度は $20 \mathrm{~mm} / \mathrm{min}$ である。

（8）工具摩耗試駼 ポンデ処理した直径 $6 \mathrm{~mm} の$ 線村をへッダーにより Fig. 3 と示す工程で据边みを 行ないその時の仕上バンキの摩耗を測定した。摩耗 は集山式表面粗さ計に上り，丹周 4 等分上て測定し。

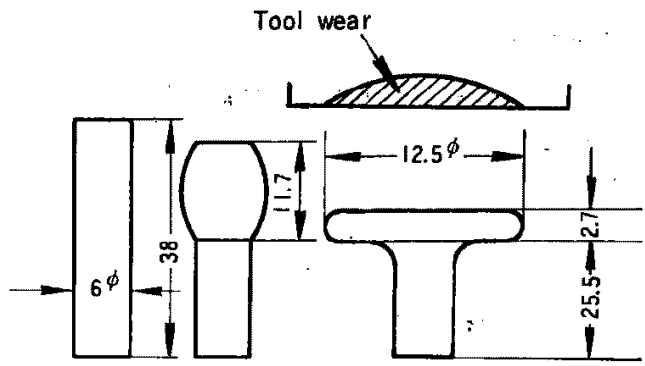

Cut-off First blow Second blow

Fig. 3. Heading sequence.

摩耗断面積の平均值を求めた。加工速度は $30 \mathrm{c} . \mathrm{p} . \mathrm{s}$ で，潤滑油は使用しない。バンタは材質 S K D 11で, かなさ $\mathrm{H}_{\mathrm{R}} \mathrm{C} 62 \sim 62.3$ ，表面粗さは $1.5 \mu$ である。

\section{3. 英験結果と考察}

\section{1 低P， S, Si 鋤の基䂵特性}

予備調查により，Si および $\mathrm{P}$ の低下により变形抵 抗が成少し， $\mathrm{S}$ の低下に上り限界ひずみが向上するこ とを確認したのち，S45C およびSCM 3 について $\mathrm{P} ， \mathrm{~S}$ および $\mathrm{Si}$ を低市し，その基碐特性をベース銅 と比較した。

Table 1 に供試材の成分を Table 2 にその製造 工程を Photo. 1 Kミク口組織の例を示す。各鋼種 の限界ひずみ，機械的性質および非金属介在物の測定 結果をTable 3 k, 圧縮変形抵抗を Fig. 4 亿示 す。

Table 3 K上れば，限界ひず 及は球状化焼鈍材边 ではR K鋼がベース鋼にくらべやや向上しているが， その後に仕上引拔を与克た材料(Dではその差は小さく なるっここで用材が间材にくらべて著しく小さいのは， 直径50mmの棒材の中心から, 直径 6 nmmの試験片女切 出したため，中心附近での值を示すことによる。 $\mathrm{RK}$ 
Table 1. Chemical composition of specimens. (in wt \%)

\begin{tabular}{l|c|c|c|c|c|c|c}
\hline Steel & $\mathrm{C}$ & $\mathrm{Si}$ & $\mathrm{Mn}$ & $\mathrm{P}$ & $\mathrm{S}$ & $\mathrm{Cr}$ & $\mathrm{Mo}$ \\
\hline S 45C & 0.48 & 0.26 & 0.67 & 0.010 & 0.010 & 0.10 & - \\
R K 1 (1) & 0.49 & 0.06 & 0.64 & 0.007 & 0.007 & 0.07 & - \\
R K 1 (2) & 0.42 & 0.04 & 0.63 & 0.007 & 0.008 & 0.08 & - \\
S C M 3 & 0.36 & 0.29 & 0.68 & 0.016 & 0.008 & 1.02 & 0.19 \\
R K 2 (1) & 0.36 & 0.06 & 0.65 & 0.009 & 0.012 & 0.96 & 0.19 \\
R K 2 (2) & 0.33 & 0.09 & 0.64 & 0.008 & 0.005 & 0.98 & 0.20 \\
\hline
\end{tabular}

Table 2. Manufacturing process of material.

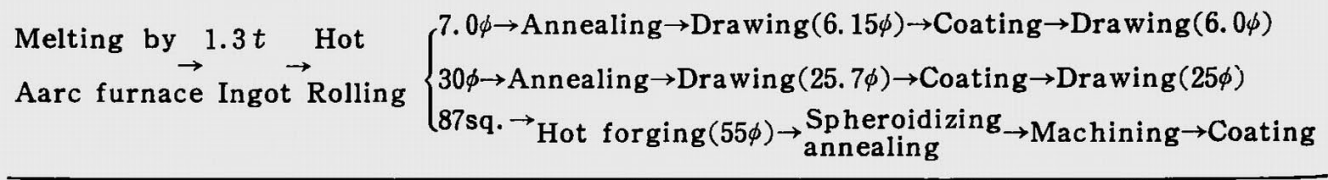
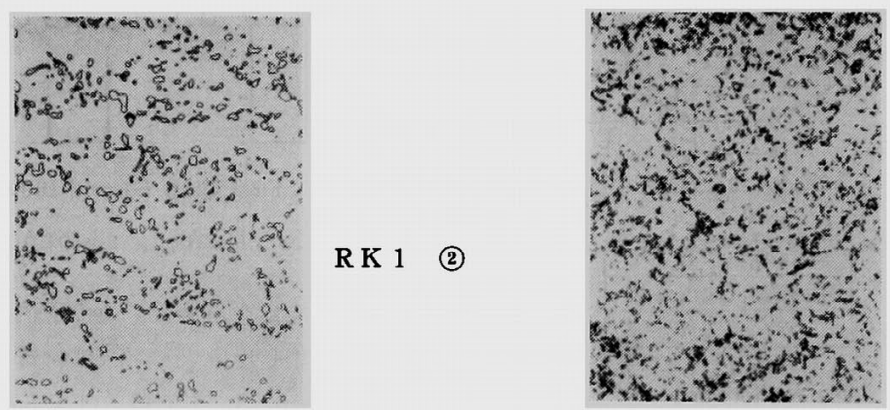

R K 2 (2)

Photo. 1. Microstructures of RK spheroidizing-annealed.

Table 3. Basic properties of low P, S, Si steel.

\begin{tabular}{|c|c|c|c|c|c|c|c|}
\hline etm & $\begin{array}{r}\text { Steel } \\
\\
\end{array}$ & $\mathrm{S} 45 \mathrm{C}$ & R K 1 (1) & R K 1 (2) & S C M 3 & R K 2 (1) & R K 2 (2) \\
\hline $\begin{array}{l}\text { Critical } \\
\text { compression } \\
\text { strain }\end{array}$ & $\begin{array}{l}\text { (D)25 } \phi \\
\text { SA } 50 \phi\end{array}$ & $\begin{array}{l}2.39 \\
1.71\end{array}$ & $\begin{array}{l}2.34 \\
1.78\end{array}$ & $\begin{array}{l}2.55 \\
1.82\end{array}$ & $\begin{array}{l}2.51 \\
1.97\end{array}$ & $\begin{array}{l}2.52 \\
2.10\end{array}$ & $\begin{array}{l}2.44 \\
2.20\end{array}$ \\
\hline $\begin{array}{l}\text { Hardness } \\
\left(\mathrm{H}_{\mathrm{v}}\right)\end{array}$ & $\begin{array}{l}\text { (D) } 6 \phi \\
\text { (D) } 25 \phi \\
\text { (SA } 50 \phi\end{array}$ & $\begin{array}{c}206 \sim 197 \\
182 \sim 172 \\
142\end{array}$ & $\begin{array}{c}167 \sim 162 \\
175 \sim 161 \\
130\end{array}$ & $\begin{array}{c}157 \sim 147 \\
162 \sim 144 \\
118\end{array}$ & $\begin{array}{c}210 \sim 201 \\
203 \sim 182 \\
164\end{array}$ & $\begin{array}{c}176 \sim 168 \\
176 \sim 168 \\
148\end{array}$ & $\begin{array}{c}178 \sim 168 \\
177 \sim 163 \\
144\end{array}$ \\
\hline Inclusion & $\begin{array}{ll} & d \\
d & A \\
d & B \\
d & C \\
\end{array}$ & $\begin{array}{l}0.12 \\
0.11 \\
0 \\
0.01\end{array}$ & $\begin{array}{l}0.08 \\
0.01 \\
0.05 \\
0.02 \\
\end{array}$ & $\begin{array}{l}0.04 \\
0.01 \\
0 \\
0.03\end{array}$ & $\begin{array}{l}0.08 \\
0.05 \\
0 \\
0.03\end{array}$ & $\begin{array}{l}0.11 \\
0.04 \\
0.04 \\
0.03\end{array}$ & $\begin{array}{l}0.02 \\
0.01 \\
0 \\
0.01\end{array}$ \\
\hline $\begin{array}{l}\text { Mechanical } \\
\text { properties } \\
\text { (D) } 6 \phi\end{array}$ & $\begin{array}{r}\sigma_{\mathrm{P}} \\
\sigma_{\mathrm{B}} \\
\mathrm{E} \\
\mathrm{R} \mathrm{A} \\
\end{array}$ & $\begin{array}{l}55.3 \\
61.9 \\
32.5 \\
62.1 \\
\end{array}$ & $\begin{array}{l}44.1 \\
51.7 \\
39.4 \\
66.5 \\
\end{array}$ & $\begin{array}{l}33.8 \\
51.9 \\
39.0 \\
66.8 \\
\end{array}$ & $\begin{array}{l}53.4 \\
59.7 \\
33.9 \\
72.9\end{array}$ & $\begin{array}{l}46.8 \\
54.1 \\
40.5 \\
72.0\end{array}$ & $\begin{array}{l}48.1 \\
54.2 \\
38.9 \\
70.3\end{array}$ \\
\hline $\begin{array}{l}\text { Mechanical } \\
\text { properties } \\
\text { (D) } 25 \phi\end{array}$ & $\begin{array}{r}\sigma_{\mathrm{P}} \\
\sigma_{\mathrm{B}} \\
\mathrm{E} \\
\mathrm{RA} \\
\end{array}$ & $\begin{array}{l}45.4 \\
51.3 \\
32.8 \\
67.1 \\
\end{array}$ & $\begin{array}{l}2.8 \\
49.1 \\
34.1 \\
68.1 \\
\end{array}$ & $\begin{array}{l}40.6 \\
46.9 \\
35.1 \\
66.8 \\
\end{array}$ & $\begin{array}{l}49.9 \\
55.8 \\
32.3 \\
72.7 \\
\end{array}$ & $\begin{array}{l}46.7 \\
51.8 \\
33.6 \\
75.5 \\
\end{array}$ & $\begin{array}{l}46.6 \\
52.0 \\
32.9 \\
74.7\end{array}$ \\
\hline $\begin{array}{l}\text { Mechanical } \\
\text { properties } \\
\text { (\$2) } 25 \phi\end{array}$ & $\begin{array}{r}\sigma_{\mathrm{P}} \\
\sigma_{\mathrm{B}} \\
\mathrm{E} \\
\mathrm{R} \mathrm{A} \\
\end{array}$ & $\begin{array}{l}33.9 \\
52.0 \\
33.8 \\
64.4 \\
\end{array}$ & $\begin{array}{l}34.9 \\
48.3 \\
35.0 \\
63.4 \\
\end{array}$ & $\begin{array}{l}33.4 \\
47.1 \\
35.6 \\
64.8 \\
\end{array}$ & $\begin{array}{l}35.0 \\
52.8 \\
33.5 \\
75.9 \\
\end{array}$ & $\begin{array}{l}34.7 \\
49.4 \\
34.3 \\
77.4\end{array}$ & $\begin{array}{l}34.3 \\
49.9 \\
34.5 \\
77.4\end{array}$ \\
\hline
\end{tabular}

(D) Drawing with reduction of $5 \%$

(\$4) Spheroidizing-annealed 


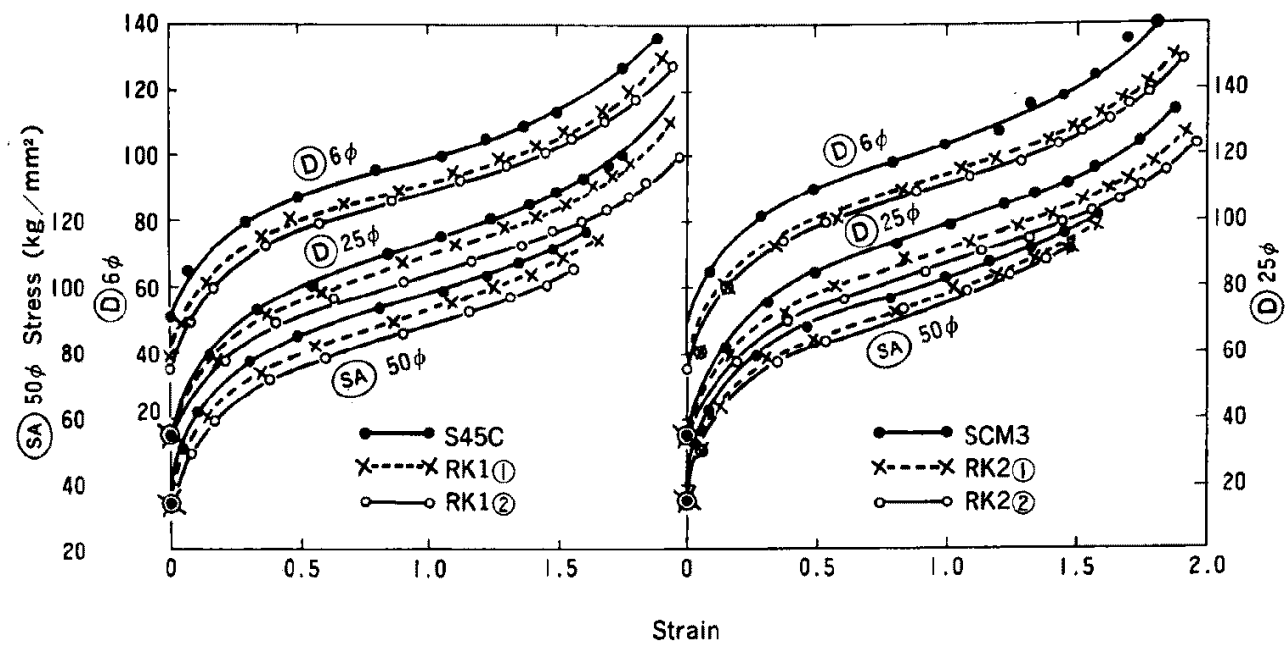

Fig. 4. Stress-strain properties in compression.

1(2)か特に大きいのは，むしろC 量の影響と思われ る。かたさは咸では $\mathrm{C} ， \mathrm{Si}$ 执よび $\mathrm{P}$ 量から推定さ れる值よりむ1.5〜1.9倍低下しており，(D材ではこの 差はさらに大きくなっている。介在物は，硫化物が

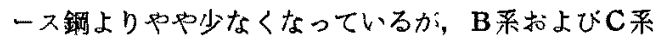
はベース鋼と同じかあるいはむしろ增加しているもの もあり，Al 量が多くなったことによる。耐力拉よび 引張強さは，R K鎑がベース銅より低下してかたさと 同じ㑯向を示し，伸びおよひ絞りは限界ひずみと同じ く、その差が小さくなっててる。

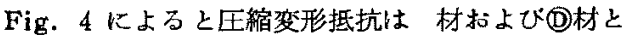
むべース鎆より $6 \sim 12 \mathrm{~kg} / \mathrm{mm}^{2}$ 低下しており, かつそ の低下量は全ひず籍用にわたって绕医一定である。

\section{2 低 $\mathrm{P}, \mathrm{S}, \mathrm{Si}$ 鈴の実用特性}

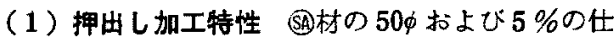
上引拔を与克た 25中ブランクを用いて，後方，前後方 怙よび前方押出し加工を行ない，加工压力ーストロー ク線図および最大加工圧力を測定した結果を Fig. 5 $\sim 8$ k示す。

押出し压力は後方，前後方扰よび前方いずれす R K

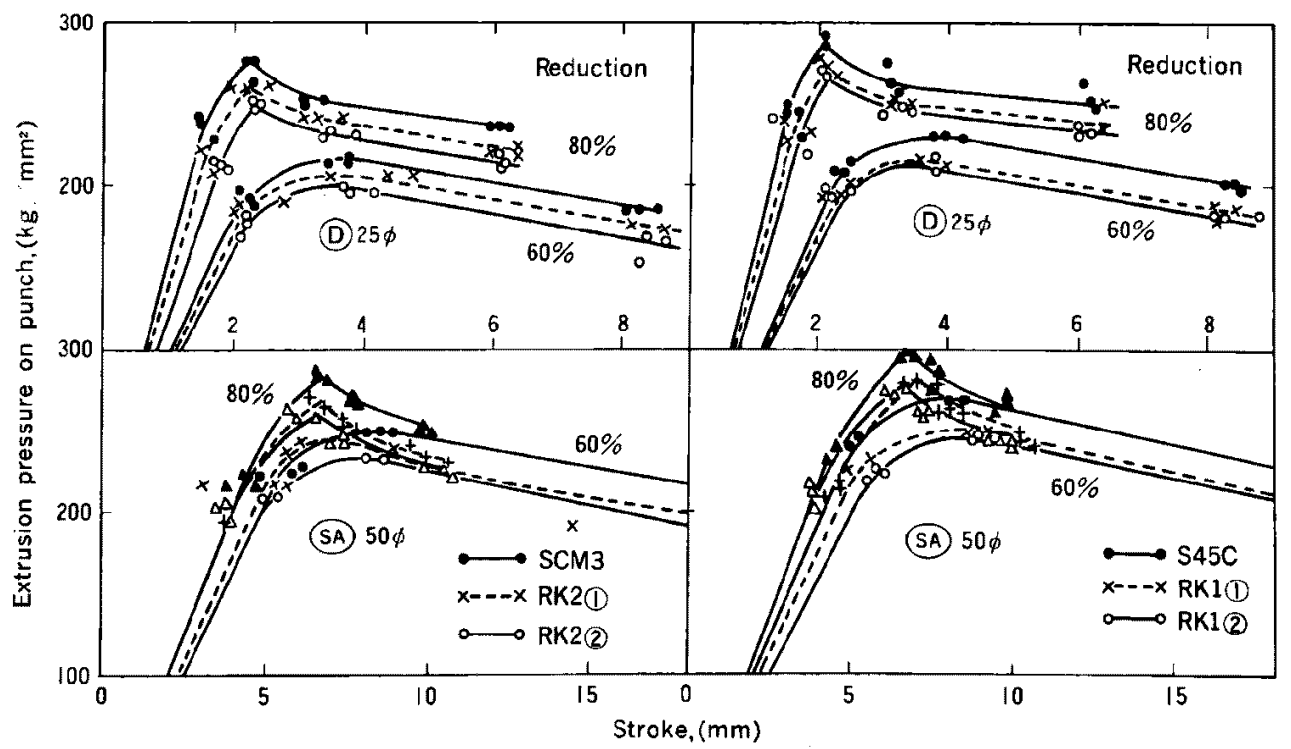

Fig. 5. Extrusion pressure-stroke diagrams in backward extrusion. 

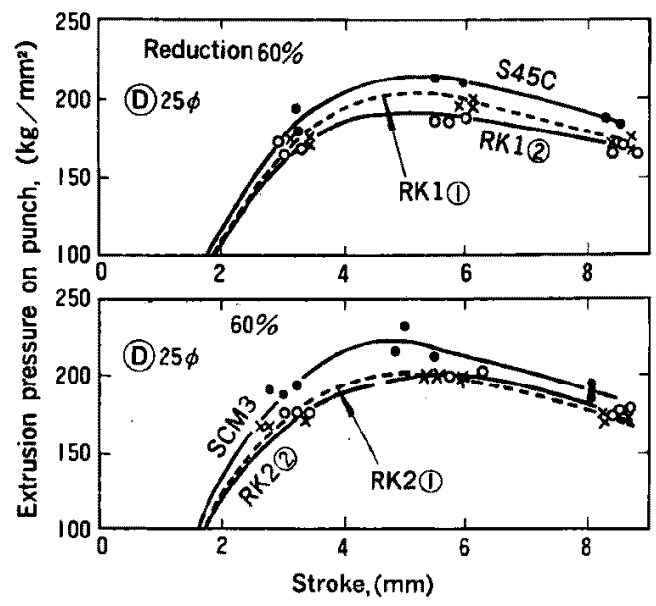

Fig. 6. Extrusion pressure and stroke diagrams in combined extrusion.
鍮がバース鎙より 6〜20kg/ $\mathrm{mm}^{2}$ 低くなっており，か つその低下量は，ストロークの全城では恬一定であ

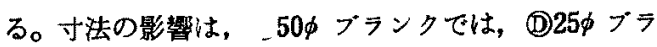
ンクにくらへ後方および前後方押出しの50 60\%減面 率で高くなっている。減面率の影響はいずれの拥出し でも50〜60\%では，加工压力は性は定となるが，80 \%減面率では著しく傐くなり，かつその程度は(D25 校の方か，かつ後方押出しの方か著しい。さらに80\% 後方捧出しでは極端なピークの発生がみられる。

押出し圧力 P は，工具と材料間の摩摖を哭視する 々, 加工条件か同一の場合には, 加工材の変形抵抗に 比例することになる。したがってべース鋼の拥出し圧 力 $\mathrm{P}_{2}$ z $\mathrm{RK}$ 鎆の拥出し压力 $\mathrm{P}_{1}$ の比は, $\mathrm{P}_{2} / \mathrm{P}_{1}$ $=2 \mathrm{k}_{1} / 2 \mathrm{k}_{2}$ となり,これは工具圧力についても同

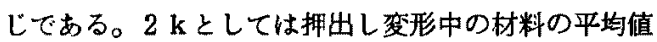

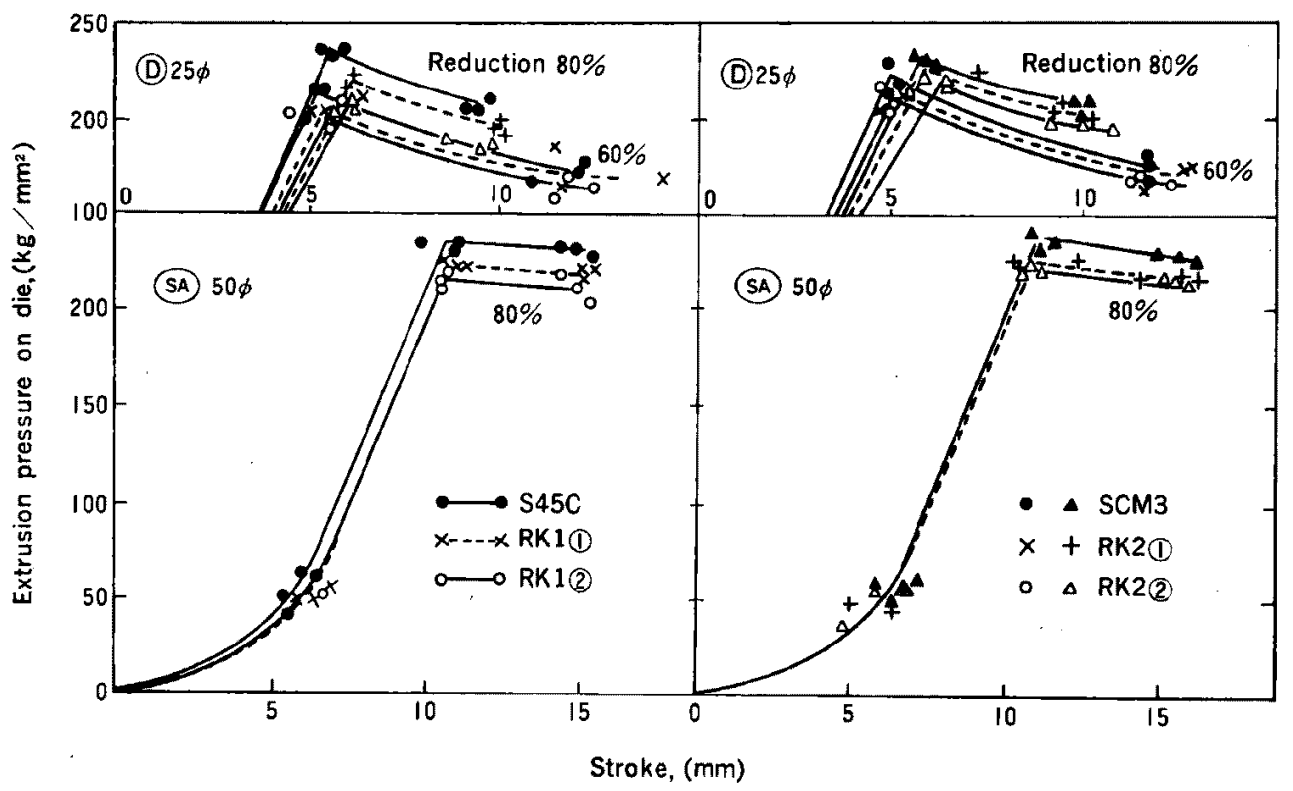

Fig. 7. Extrusion pressure-stroke diagrams in forward extrusion.

として $\varepsilon=0 \sim \varepsilon_{0}=(2 / \sqrt{3}) P / 2 \mathrm{k}$ での平均值を用

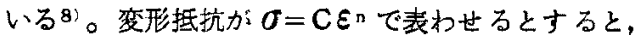
押出し匤力比は次式となる。

$$
\begin{gathered}
\mathrm{P}_{1} / \mathrm{P}_{2}=\int_{0}^{\varepsilon_{0}} \sigma_{1} d \varepsilon / \int_{0}^{\varepsilon_{0}} \sigma_{2} d \varepsilon=\left(\mathrm{C}_{1} / \mathrm{C}_{2}\right)\left\{\left(\mathrm{n}_{2}+1\right)\right. \\
\left./\left(\mathrm{n}_{1}+1\right)\right\} \varepsilon_{0} \mathrm{n}_{1}-\mathrm{n}_{2} \ldots \ldots \ldots \ldots \ldots \ldots \ldots \ldots \ldots \ldots \ldots \ldots \ldots \ldots \ldots \ldots \ldots \ldots \ldots \ldots \ldots \ldots \ldots
\end{gathered}
$$

P/2 k としては，後方および前方佣出しに対してお のおの(2)および(3)式を用い，かつ Fig. 4 の結果から ひずみ $0.1 〜 1.0$ での C 拈よびn值を最少自乗法で 求め，押出し圧力の比を計算および央測した結果を Table 4 および Fig.9 に示す。
Table 4. $\mathrm{C}$ and $\mathrm{n}$ value.

\begin{tabular}{l|r|r|r|r}
\hline \multirow{2}{*}{ Steel } & \multicolumn{2}{|c|}{ (D25 } & \multicolumn{2}{c}{$50 \phi$} \\
\cline { 2 - 5 } & $\mathrm{C}$ & $\mathrm{n}$ & $\mathrm{C}$ & $\mathrm{n}$ \\
\hline S 45 C & 94.0 & 0.236 & 97.8 & 0.214 \\
R K 1 (1) & 89.5 & 0.238 & 93.0 & 0.224 \\
R K 1 (2) & 84.0 & 0.239 & 87.0 & 0.214 \\
S C M 3 & 98.5 & 0.232 & 103.0 & 0.193 \\
R K 2 (1) & 91.8 & 0.248 & 97.0 & 0.201 \\
R K 2 (2) & 85.7 & 0.241 & 97.0 & 0.196 \\
\hline
\end{tabular}




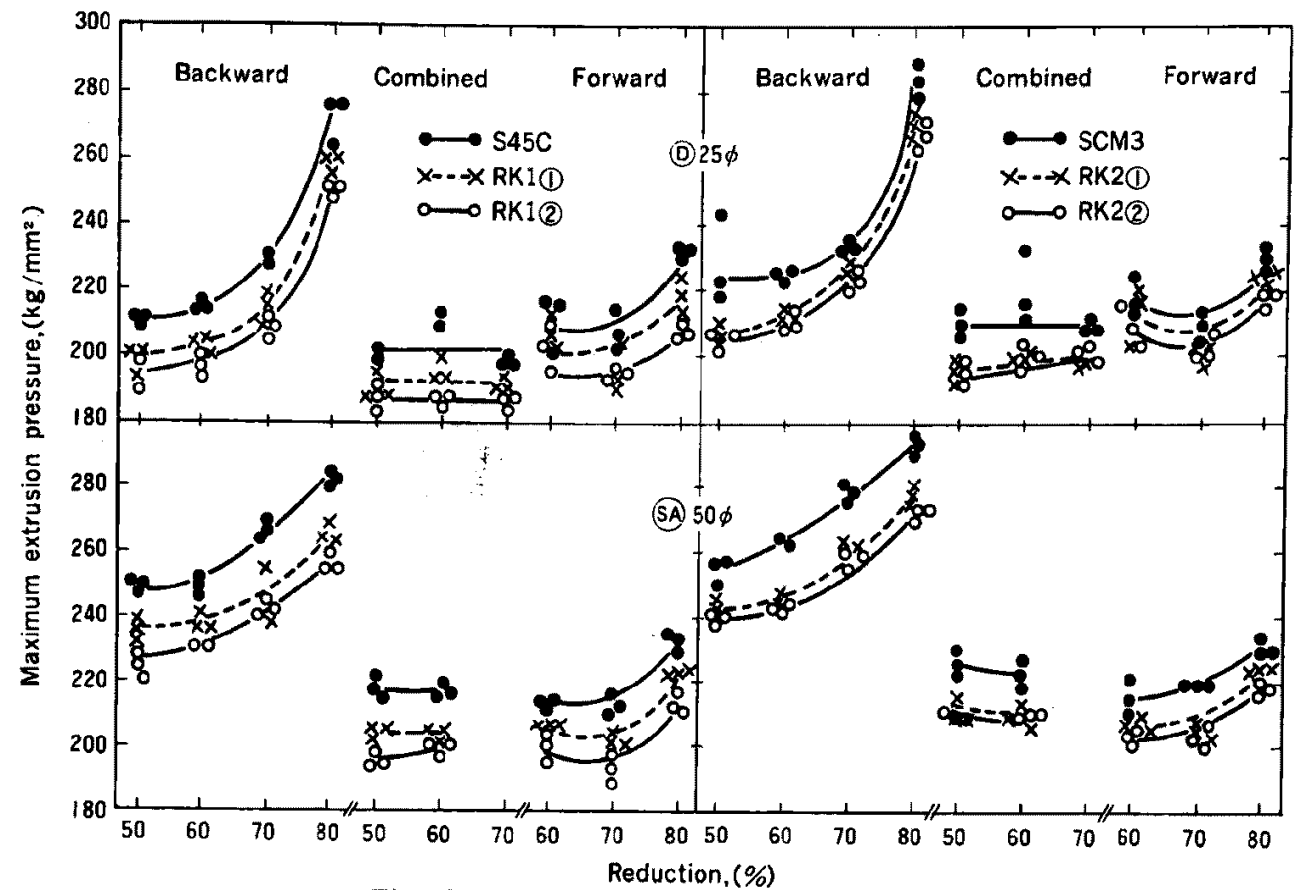

Fig. 8. Maximum extrusion pressure.

後方㧑出し $P / 2 k=2 \sqrt{(1-r) / r}+(7 / 8) \sqrt{r /(1-r)} 9$

前方押出L $\mathrm{P} / 2 \mathrm{k}=1.2(\alpha / 90)+\{0.74+0.22(\alpha / 90)\} \ell_{\mathrm{n}} \mathrm{R} 10$

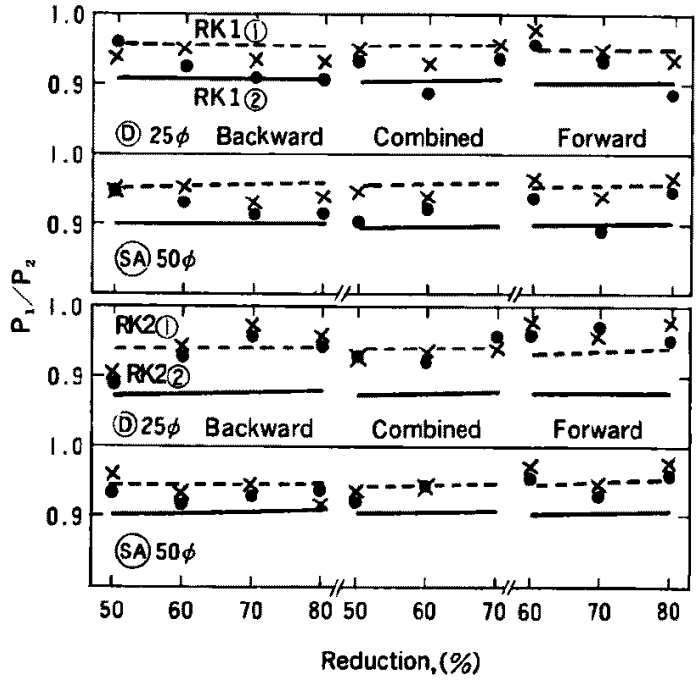

Fig. 9. Extrusion pressure ratio.

$\mathrm{r}=\mathrm{d} / \mathrm{D}, \mathrm{R}=\left(1 / \mathrm{r}^{2}\right)-1, \mathrm{D}:$ エンテナー直径,

$\mathrm{d}$ : 前方押出しではダイス直径, 後方押出しではポン チ直径, $a$ :ダイス半角

Table 4 によると， n 值は R K 鐧とベース鋼はは ほ同しかかるいはわずかに前者が大きくなっており，
C值はR K 鉿がさくなっている。また仕上引抜を与 えた材料では，n值が大きくなり，バウシンがー効果 によるものと思われる。Fig.9 によると押出しE力 の低下の実測值は計算值よりやや小さくなっている。

つぎに押出し加工時の加工割れの発生であるが, こ れは $50 \phi$ 材の前後方押出し加工時に, その表面に, 中周方向に伸び，かつ表面から䄪 $45^{\circ}$ 方向に内部に進 む表面割れか認められた。この割れが発生したときの

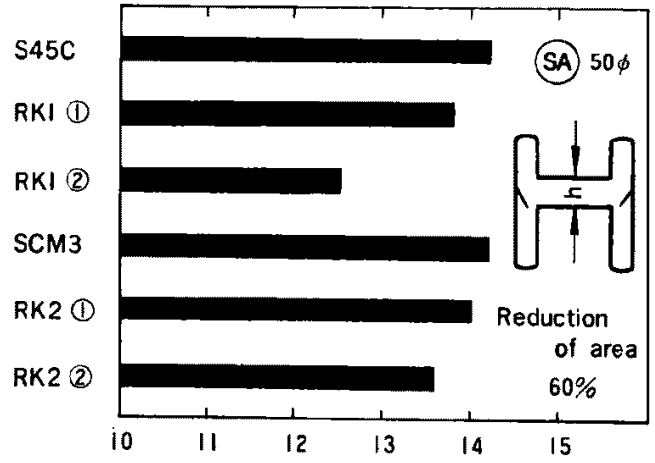

h, $(\mathrm{mm})$

Fig. 10. Critical base thickness in combined extrusion. 


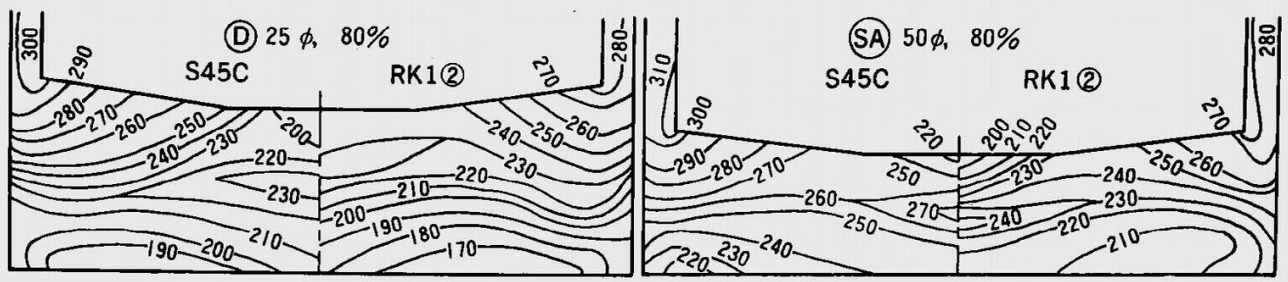

Fig. 11. Distribution of vickers hardness in backward extruded parts.

底厚の測定結果を Fig. 10 に示す。この割れの発生 限度は, R K 鋼がベース鋼にくらべて大きく, Table 3 の限界ひずみと同じ傾向を示す。このよ 5 に表面拊束 を受けた状態での㓻れ発生のしやすさについても，圧 縮試験における限界ひずみから定性的に推定できる。 押出し加工品のかたさは，その一例を Fig. 11 に

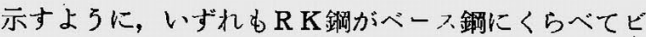
ッカースで10〜20低くなっており，ブランクでのかた さの差とほほ同じ差をもっている。また，かたさ分布 の様式は鍮種による差はみられない。

メタルフローの例を Photo. 2 に示すか，いずれ の鉡種でもほ辛同様のフローを示す。

前方押出し材から削り出した試験片によって，引張 試験した結果の一例を Fig. 12 に示す。引張強さお よび耐力は R K 堸がベース鋼より $4 \sim 15 \mathrm{~kg} / \mathrm{mm}^{2}$ 低く なっており，ブランクでの值よりもその差は大きい。

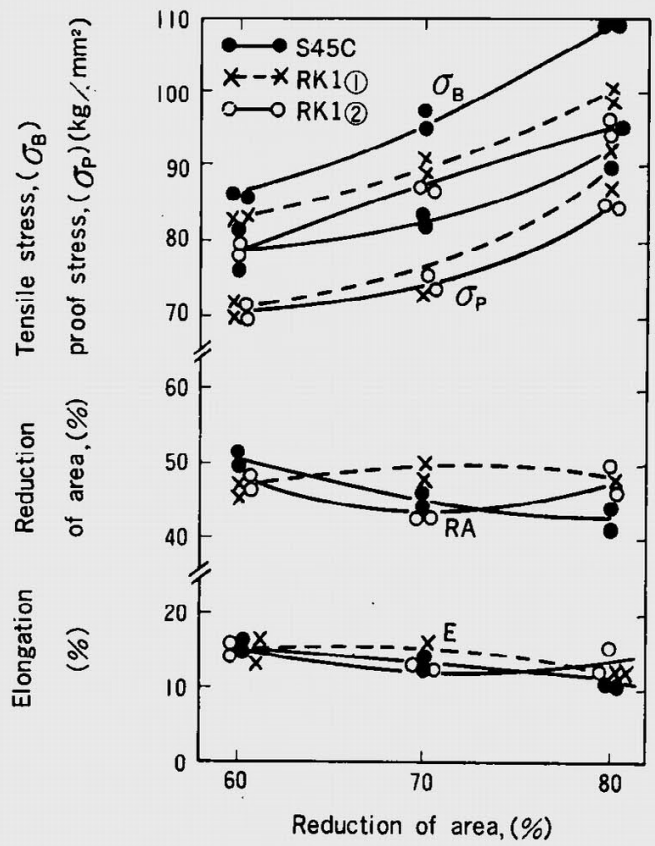

Fig. 12. Mechanical properties in forward extruded parts.

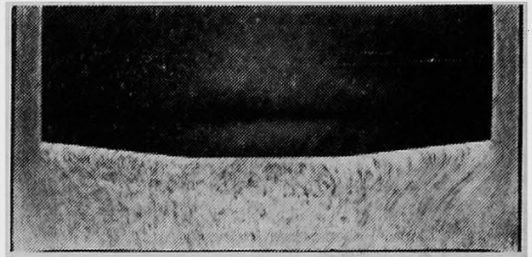

Photo. 2. Plastic flow in backward extruded part.

伸びおよび絞りについては大きな差はない。

（2）パックリング性，後 $5 \%$ の仕上引技を与之 た直径 $6 \mathrm{~mm}$ の線材について，両端拘束での限界据込 み比を測定した結果を Fig. 13 に示す。限界据込み 比はR K 鋼はいずれもベース鎆より大きくなってお り，その程度はn值に比例している。

（3）盛上り性 (D)25p のブランクを, Fig. 2 の ポンチにより60\%圧縮したときの，中心穴への材料の 盛上り高さを測定した結果を Fig. 14 に示す。いず れもかたさの低いRＫ１およびRＫ２がベース鋼にく らへてて盛上りがずかによくなっている。

（4）トリミング性 (D) $6 \phi$ の材料を $87 \%$ 据还んた 後トリミングしたときのせん断応力扰よび製品のか えり高さの測定結果を Fig. 15 に示す。RK 鋼はい ずれもべース鋼よりせん断応力で6.5〜9.5\%小さくな

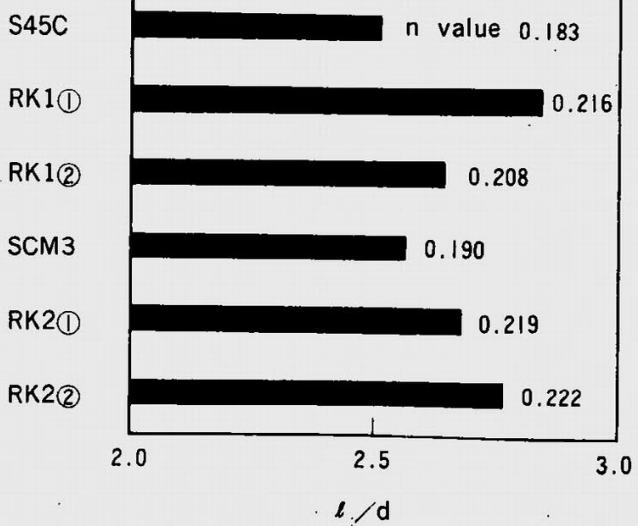

Fig. 13. Critical upsetting ratio. 


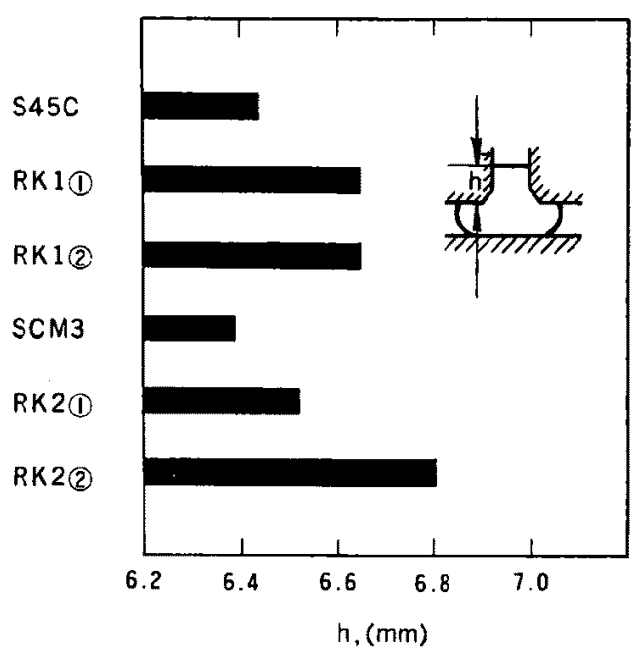

Fig. 14. Open-die extrusion.

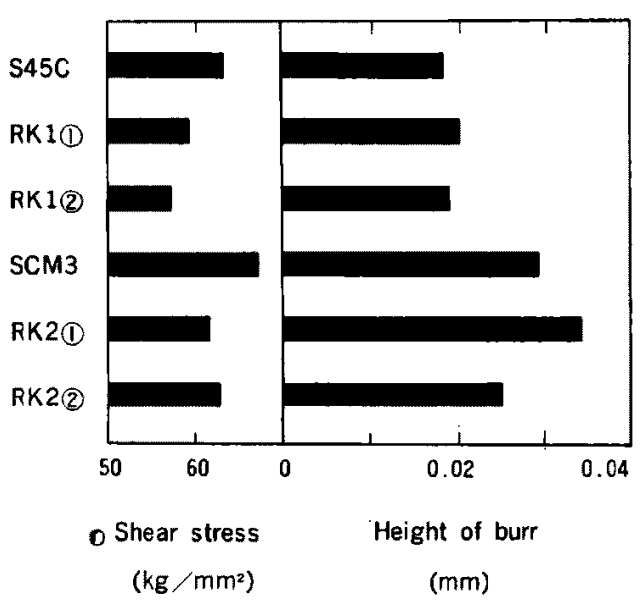

Fig. 15. Trimming.

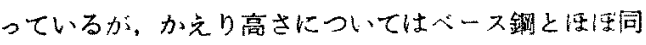
じかしる大きくなっている。

(5) せん断性 (D)25中の棒材についてて，半円形力 ッターによりせん断したときのせん断応力および切口 形状を Fig，16に示与。せ九断応力はトりミンりの 場合々同様に，RK 鋼がベース鋼よりも5.5〜10\%低 くなっている。如口形状については，たれはダイス側 切口てはR K銅の方がさくなっているか，カッター 側切口では大差がない。せん断面長さは，カッター㑡

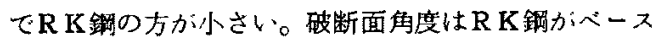
銅よりやや大きくなっている。

(6) 工具歷試験 $6 \phi$ の線材を 2 段へッダーに より，圧下率78\%で据込み，そのときのポンチ摩耗を 測定した結果を Fig. 17 と示す。 S45C 系では加工

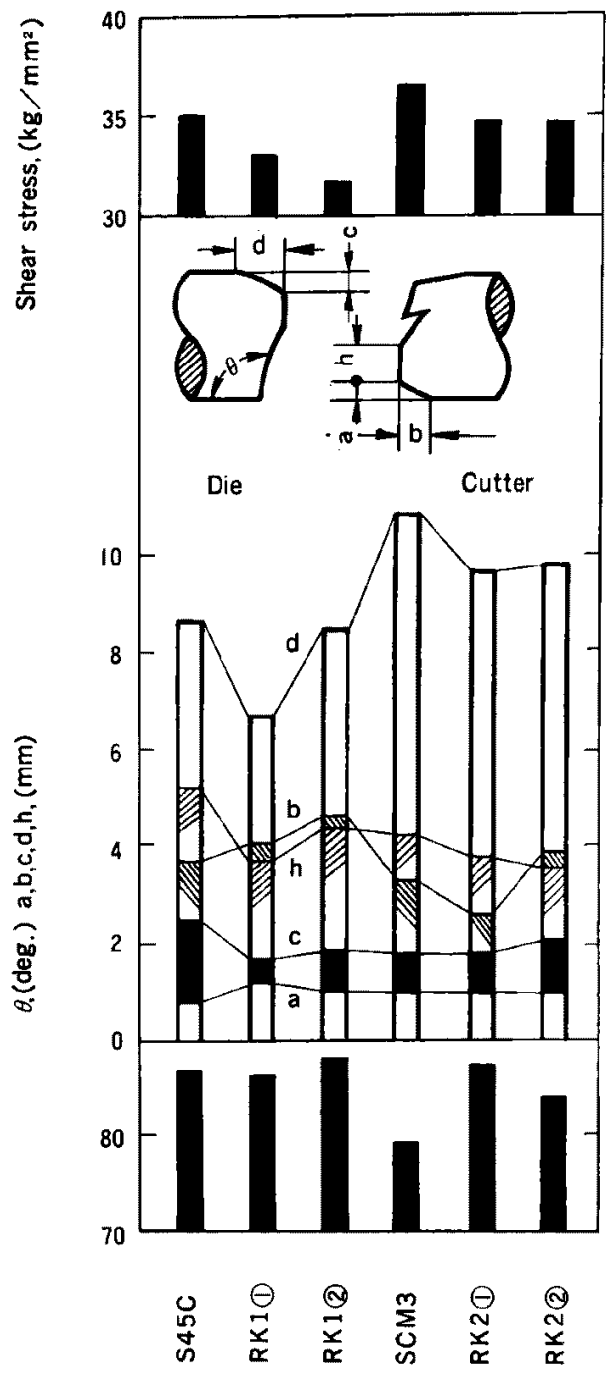

Fig. 16. Blanking.

数 4,000 5,000 未では初期摩耗で摩耗速度は平い わ，その後は定常摩耗となり，一定の摩耗速度に落着 く。S C M 3 采は加工数 $3,000 〜 5,000$ て定常摩耗とな る。これらの定常摩耗はRK 1 はS 45Cの 1/1.4〜 1 2. 5，RK 2 は S M 3の1/1.5と著しく少なくなっ ており，かつS CM 3 系はS 45C系より 女工具摩耗を 著しく大きくする。 


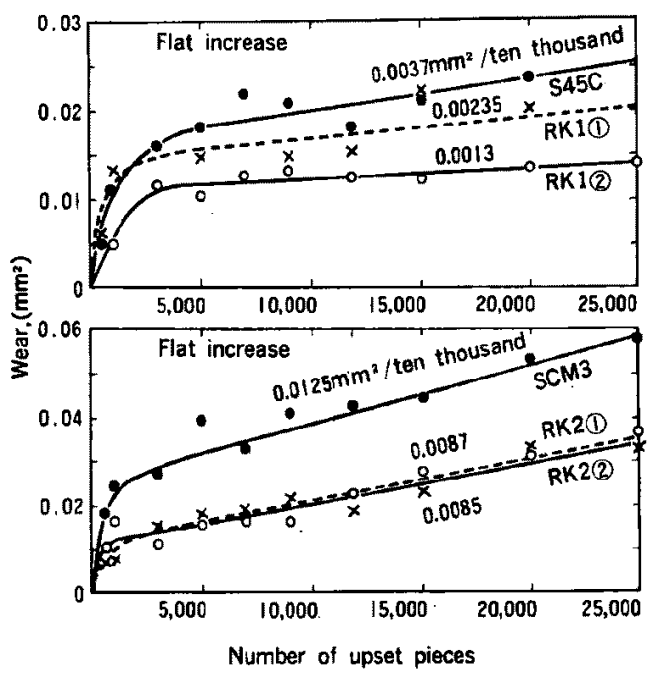

Fig. 17. Wear of punch.

\section{4. 殸}

以上， S45Cおよび S CM 3 について，P， Sおよ びSi 含有量の低下が，実用冷鍛特性におよ活す影響 を調査した結果

(1) P $P$ 上び Si の低下に上り，变形抵抗曲線の C 值は著しく低下し， $\mathrm{n}$ 值はごくわずか炕增加する。 の低下は A 系介在物を減じて限界ひずみを向上する が，引抜予加工を与克た材料の圧縮では，この効果は 減じられる。

（2）押出し加工では，前方，後方拉よび前後方押出 しとも， R K鋼の加工圧力は，変形抵抗曲線から推定 できるだけの減少を示し，また加工割れについては， 前後方押出しで，限界ひずみと同じ傾向の割れやすさ を示す。

押出七加工材の機械的性質において，かたさは活活 加工前での差と同じ差をもち，耐力および引張強さ は，加工前での差より大きくなる傾向がある。
（3）据迈灭に批ける限界据込み比は，RK鋮がやや 大きく， $\mathrm{n}$ 值に此例している。

(4) 盛上り性は， R K 鎆が盛上り高さで 0.1 0.4 $\mathrm{nm}$ とわずかに大きい。

(5) トリミング性は， RK K鍓は世ん断応力は著しく 小さくなるがか觉りについては差がない。

(6) 女ん断性は，せん断応力はR K鋼か㒂しく小さ くなるが，切口の形状についてはほとんど差がない。

(7) ヘッダ一加工に捕ける工具摩耗は，R K銅が著 しく小さく、ベース鎆の 1/1.4〜 1/2.5である。 な怙本研究は，命鈠用鋼研究グルーブ内のテーマの 一つとして実施したものであり，研究第 1 部長伊藤哲 朗氏の指導と藤倉リーダー他メンバーの協力に謝意を 表します。

$$
\text { （女 献） }
$$

1） E. C. Bain 著，椙山訳；銅中の合金元素の機 能, (1942) 87 , 科学主義工業社

2) C. E. Cacy and M. Gensamer; Trans. AS M, 32 (1944), 88

3) D. J. Blickwede; Metal Progress, 97 (1970) 5,76

4) J. L. Hurley, A. L. Kitchin and R. R. Crawford; Metal Engng. Quartery, 11 (1971) 3, 36

5) J.A. Rinebolt; Metal Progress, 96 (1969) 3, 117

6）武田, 大野; 住友金属, 22 (1970) 3， 284

7）大野；鉄と鍓，56（1970）4, 204

8）工藤他; 巨本機械学会誌，67 (1964) 542, 392

9) H. Kudo; Intern. J. Mech. Sci. 1 (1960), 57

10）室田他; 日本機峨学会誌, 73 (1970) 614, 371 